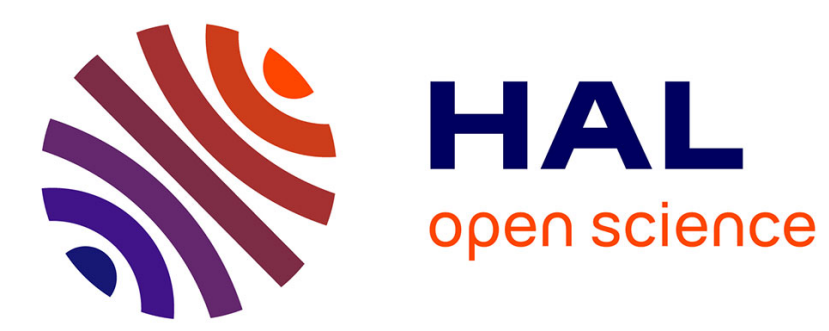

\title{
Reply to letter by Efe et al.
}

\author{
Andrew David Yeoman, Michael A Heneghan
}

\section{To cite this version:}

Andrew David Yeoman, Michael A Heneghan. Reply to letter by Efe et al.. Alimentary Pharmacology and Therapeutics, 2010, 32 (1), pp.115. 10.1111/j.1365-2036.2010.04316.x . hal-00552554

\section{HAL Id: hal-00552554 https://hal.science/hal-00552554}

Submitted on 6 Jan 2011

HAL is a multi-disciplinary open access archive for the deposit and dissemination of scientific research documents, whether they are published or not. The documents may come from teaching and research institutions in France or abroad, or from public or private research centers.
L'archive ouverte pluridisciplinaire HAL, est destinée au dépôt et à la diffusion de documents scientifiques de niveau recherche, publiés ou non, émanant des établissements d'enseignement et de recherche français ou étrangers, des laboratoires publics ou privés. 


\begin{tabular}{l}
\hline Alimentary Pharmacology \\
\hline \& Therapeutics \\
\hline
\end{tabular}

\section{Reply to letter by Efe et al.}

\begin{tabular}{|c|c|}
\hline Journal: & Alimentary Pharmacology \& Therapeutics \\
\hline Manuscript ID: & APT-0265-2010 \\
\hline Manuscript Type: & Letter to the Editors \\
\hline $\begin{array}{r}\text { Date Submitted by the } \\
\text { Author: }\end{array}$ & 01-Apr-2010 \\
\hline Complete List of Authors: & $\begin{array}{l}\text { Yeoman, Andrew; King's College Hospital, Institute of Liver Studies } \\
\text { Heneghan, Michael; King's College Hospital, Institute of Liver } \\
\text { Studies }\end{array}$ \\
\hline Keywords: & $\begin{array}{l}\text { Liver < Organ-based, Autoimmune liver disease < Hepatology, } \\
\text { Clinical pharmacology < Topics, Immunosuppression < Topics }\end{array}$ \\
\hline
\end{tabular}

\section{ScholarONE


We thank Dr Efe and colleagues ${ }^{1}$ for their interest in our review article regarding the modern management of autoimmune hepatitis (AIH). ${ }^{2}$ Tumour necrosis factor (TNF)alpha, clearly plays a major role in promulgating autoimmune processes and, indeed, has been implicated in the pathogenesis of $\mathrm{AIH} .{ }^{3}$ In addition, an association has been identified between genetic polymorphisms in the TNF promoter region and type I AIH which, significantly, was also associated with higher rates of cirrhosis and poorer responses to corticosteroids. ${ }^{4,5}$ However, in respect of the management of AIH, we feel it is important to proceed with caution in respect of agents that block TNF-alpha for the following reasons.

Firstly, the evidence for their use comes from very few, single case reports, ${ }^{6,7}$ with therapy in one report instituted for non AIH indications. ${ }^{5}$ Secondly, these agents appear to be potentially hepatotoxic, which is clearly undesirable in a hepatic disease process such as AIH. ${ }^{8}$ Indeed, AIH has actually been shown to be precipitated by TNF-alpha therapy. ${ }^{9}$ Finally, there remains the concern surrounding the risk of opportunistic infection. Indeed, in the case report cited by Dr Efe and colleagues ${ }^{6}$, the patient suffered 2 infection related complications necessitating withdrawal of therapy. Interestingly this patient was not managed with either tacrolimus or cyclosporine.

Consequently we believe the vast majority of AIH patients non responsive to standard therapy can be successfully managed through better implementation of longer established, non-hepatotoxic immunosuppressive therapies (MMF, tacrolimus, ciclosporin) whose side effect profile is well understood. Whilst it is accepted that, conceptually at least, TNF-alpha therapies may be novel agents in difficult to treat $\mathrm{AIH}$, their use is little studied in this context with particular concerns existing over their safety. For these reasons their utility was not expanded upon in this review and their future use should be limited to clinical trials. 


\section{References:}

1. Efe C, Purnak T, Ozaslan E. Anti TNF- $\alpha$ therapy can be a novel treatment option in patients with autoimmune hepatitis (letter). Aliment Pharmacol Ther 2010 ; in press.

2. Yeoman AD, Longhi MS, Heneghan MA. Autoimmune hepatitis - modern management. Aliment Pharm and Ther 2010;31:771-87.

3. Maggiore G, Bennedetti F, Massa M et al. Circulating level of interleukin-6, interleukin- 8 and tumour necrosis factor-alpha in children with autoimmune hepatitis. J Paediatr Gastroenterol Nutr 1995;20:23-7.

4. Cookson S, Constantini PK, Clare M, et al. Frequency and nature of cytokine gene polymorphisms in type 1 autoimmune hepatitis. Hepatology 1999;30:851-6.

5. Czaja AJ, Cookson S, Constantini PK et al. Cytokine polymorphisms associated with clinical features and treatment outcome in type 1 autoimmune hepatitis. Gastroenterology 1999;117:645-52.

6. Weiler-Normann C, Wiegard, C, Schramm C et al. A case of difficult to treat autoimmune hepatitis successfully managed b TNFR-alpha blockade. Am J Gastroenterol 2009;104:2877-8.

7. Goldenberg G, Jorizzo JL. Use of etancercept in a the treatment of pyoderma gangrenosum in a patient with autoimmune hepatitis. J Dermatolog Treat $2005 ; 16: 347-9$

8. Tobon GJ, Canas C, Jaller JJ et al. Serious liver disease induced by infliximab. Clin Rheumatol 2007;26:578-81.

9. Ramos-Casals M, Roberto-Perez-Alvarez, Diaz-Lagares C et al. Autoimmune diseases induced by biological agents: A double-edged sword? Autoimmun 
Rev 2010;9:188-93. 